\title{
ANALISIS UJI VALIDITAS TES BUATAN GURU BAHASA BUGIS DENGAN MENGGUNAKAN ARTIFICIAL INTELLIGENCE (AI) KELAS IX 1 SMPN 1 LABAKKANG KABUPATEN PANGKEP
}

\author{
Andi M.Yusuf \\ andymyusuf@gmail.com
}

\begin{abstract}
ABSTRAK
Tujuan penelitian ini adalah untuk menjelaskan analisis uji validitas tes buatan guru bahasa Bugis dengan menggunakan Artificial Intelligence (AI) kelas IX 1 SMPN 1 Labakkang Kabupaten Pangkep. Jenis penelitian yang digunakan adalah penelitian kualitatif yang bersifat deskriptif. Data penelitian adalah tes-tes buatan guru sekolah yang telah diberikan kepada siswa. Sumber data penelitian ini adalah sumber tertulis berupa silabus, RPP kisi-kisi, soal (tes) yang telah dibuat guru bahasa Bugis SMPN 1 Labakkang Kabupaten Pangkep. Hasil penelitian ini Piranti Lunak Artificial Intelligence (Al) (Test-Analysis Software) berjalan sesuai yang diharapkan. Analisis uji validitas tes buatan guru menggunakan Artificial Intelligence (Al) berupa soal uraian menggunakan empat instrumen. Adapun keempat instrumen dalam menguji validitas, yaitu 1) penilaian RPP yang berada pada tataran kategori baik atau valid. 2) pengamatan uji validitas yang berada pada kategori sangat baik atau sangat valid. 3) respon siswa yang terdiri tiga kategori validitas soal (27\%) yang tidak valid atau respon yang kurang baik dan respon peserta didik terhadap tes buatan guru bahasa Bugis menunjukkan valid atau respon yang baik berjumlah 24 siswa (73\%). 4) analisis butir soal yang terdiri dari kategori sangat tinggi terdapat dua butir soal, yaitu butir soal ke1 dan ke-4 (28.6 \%), kategori tinggi, yaitu tiga butir soal berkategori tinggi, yaitu butir soal nomor ke-5, ke-6, dan ke-7 (42.8 \%), dan kategori sedang, terdapat dua butir soal berkategori sedang, yaitu butir soal nomor 2 dan 3 (28.6). Pengujian validitas tes buatan guru ini menyatakan bahwa tes buatan guru ini berdasarkan pengkategorian validitas isi, konstruk, dan kriteria/empiris adalah valid.
\end{abstract}

\section{ABSTRACT}

The purpose of this study was to clarify the validity of the test analysis Bugis language teachermade tests using Artificial Intelligence (AI) class IX 1 SMPN 1 Labakkang Pangkep This type of research is descriptive qualitative research. The research data is a teacher-made tests Bugis language SMPN 1 Labakkang Pangkep that have been given to students. Source of this research data is written sources or documents such as syllabus, RPP lattice, questions (tests) have been made Bugis language teacher at SMPN 1 Labakkang Pangkep. The results of this study Software Artificial Intelligence (Al) (Test-Analysis Software) work as expected. Analysis of test validity teacher-made tests using Artificial Intelligence (Al) descriptions using four instruments. As for the four instruments in testing the validity, namely 1) vote RPP that are at the level of either category or valid. 2) test the validity observations that are in the category of very good or very valid. 3) the response of students consisting of three categories of the validity of the matter (27\%) were invalid or unfavorable response and the response of learners towards Bugis language teacher-made tests indicate valid or good responses totaling 24 students (73\%). 4) analysis of items consisting of very high category, there are two items, ie items 1 and 4 (28.6\%), high category, namely three items high category, namely items numbers to the 5 th, -6 , and 7 (42.8\%), and the medium category, there are two items categorized as moderate, ie items number 2 and 3 (28.6). Testing the validity of teacher-made tests have stated that this teacher-made tests based on the categorization of content validity, construct and criterion / empirically valid. 


\section{Journal Of Computer and Information System (J-CIS) ISSN 2622-0881 (online)}

\section{PENDAHULUAN}

Penelitian pendidikan khususnya penelitian kuantitatif dikenal dengan nama variabel, misalnya variabel laten, variabel manifes, dan sebagainya. Variabel inilah yang pada umumnya ingin diketahui karakteristik yang dimilikinya, misalnya rata-rata, median, modus, standar deviasi dan lain-lain. Untuk mengukur suatu variabel diperlukan alat ukur yang biasa disebut instrumen.

Djaali (2000:9) menyatakan bahwa secara umum yang dimaksud dengan instrumen adalah suatu alat yang karena memenuhi persyaratan akademis. Instrumen dapat dipergunakan sebagai alat untuk mengukur suatu objek ukur atau mengumpulkan data mengenai suatu variabel. Instrumen dapat dibagi menjadi dua macam, yakni tes dan dan nontes. Kelompok tes, misalnya tes prestasi belajar, tes intelegensi, dan tes bakat; sedangkan yang termasuk non-tes, misalnya pedoman wawancara, angket atau kuesioner, lembar observasi, daftar cocok (check list), skala sikap, skala penilaian, dan sebagainya.

Weitzenhoffer (Nur, 1987: 1) menyatakan bahwa pengukuran sebagai suatu operasi yang dilakukan terhadap alam fisik oleh pengamat, misalnya ingin mengukur hasil belajar, intelegensi, sikap, motivasi berprestasi, dan sebagainya. Alat ukur benar-benar dapat mengukur dan sejauh mana alat ukur tersebut dapat diandalkan dan berguna. Alat ukur sebenarnya menunjuk pada dua hal yang pokok, yaitu validitas dan reliabilitas.

Tes dikatakan memiliki validitas jika tes tersebut dengan secara tepat, benar, sahih, atau absah dapat mengukur yang seharusnya diukur, yaitu mengukur hasil belajar yang telah dicapai oleh siswa setelah mereka menempuh proses belajar mengajar dalam jangka waktu tertentu. Validitas suatu tes dapat dianalisis secara logika (logical analysis) dan secara empirik (empirical analysis), misalnya tes masuk di SMA. Tes masuk harus selalu dikaitkan dengan seberapa jauh tes masuk tersebut dapat mencerminkan prestasi atau hasil belajar para calon peserta didik baru setelah belajar nanti.

Tes juga dapat dikatakan memiliki reliabilitas jika hasil-hasil pengukuran yang dilakukan dengan menggunakan tes tersebut secara berulang kali terhadap subjek yang sama, senantiasa menunjukkan hasil yang tetap atau sifatnya ajek dan stabil. Artinya, tes memiliki reliabel jika nilainilai yang diperoleh para tester adalah stabil kapan saja, dimana saja, dan oleh siapa saja ujian itu dilaksanakan, diperiksa, dan dinilai.

Suryabrata (2000: 41) menyatakan bahwa validitas tes pada dasarnya menunjuk kepada derajat fungsi pengukurnya suatu tes, atau derajat kecermatan ukurnya sesuatu tes. Validitas suatu tes mempermasalahkan bahwa tes tersebut benar-benar mengukur apa yang hendak diukur. Seberapa jauh suatu tes mampu mengungkapkan dengan tepat ciri atau keadaan yang sesungguhnya dari objek ukur, akan tergantung dari tingkat validitas tes yang bersangkutan.

Nurkancana (1992: 141) menyatakan bahwa suatu alat pengukur dapat dikatakan alat pengukur yang valid apabila alat pengukur tersebut dapat mengukur apa yang hendak diukur secara tepat. Validitas dan reliabilitas, tentunya dipengaruhi oleh (1) instrumen, (2) subjek yang diukur, dan (3) petugas yang melakukan pengukuran. Pengukuran sendiri, khususnya dalam pendidikan tentunya yang terpenting adalah informasi hasil ukur yang benar. Hasil ukur yang tidak atau kurang tepat akan memberikan informasi yang tidak benar sehingga kesimpulan yang diambil juga tidak benar.

Dewasa ini, (Sutojo. 2010) menyatakan bahwa Artificial Intelligence (Al) adalah salah satu cabang ilmu pengetahuan berhubungan dengan pemanfaatan mesin untuk memecahkan persoalan yang rumit dengan cara yang lebih manusiawi. Hal Ini biasanya dilakukan dengan mengikuti/ mencontoh karakteristik dan analogi berpikir dari kecerdasan manusia, dan menerapkannya sebagai algoritma yang dikenal oleh komputer. Pendekatan lebih fleksibel dan efisien dapat diambil tergantung dari keperluan yang memengaruhi wujud dari perilaku Artificial Intelligence $(\mathrm{Al})$. 
Artificial Intelligence (Al) biasanya dihubungkan dengan ilmu komputer, akan tetapi juga terkait erat dengan bidang lain seperti Matematika, Psikologi, Pengamatan, Biologi, Filosofi, Bahasa, dan yang lainnya. Kemampuan untuk mengkombinasikan pengetahuan dari semua bidang ini pada akhirnya akan bermanfaat bagi kemajuan dalam upaya menciptakan suatu Artificial Intelligence $(\mathrm{Al})$.

Komputer dapat bertindak seperti dan sebaik manusia, jika diberi bekal pengetahuan dan mempunyai kemampuan untuk menalar. Artificial Intelligence (Al) akan mencoba untuk memberikan beberapa metode untuk membekali komputer dengan kedua komponen tersebut agar komputer bisa menjadi mesin pintar.

Berdasarkan pemikiran tersebut, maka kami akan melakukan analisis uji validitas tes buatan guru bahasa Bugis dengan menggunakan Artificial Intelligence (AI) yang terlebih dahulu merancang dan membuat Piranti Lunak Artificial Intelligence (AI) tersebut. Piranti lunak ini diharapkan mampu mengukur tingkat validitas tes buatan guru bahasa Bugis di SMPN 1 Labakkang. Analisis uji validitas tes buatan guru bahasa Bugis diharapkan akan memiliki nilai manfaat praktis, tingkat efektivitas, dan efisiensi karena hasil yang diperoleh dari penerapan tes itu akan diperoleh skor yang sahih dan konsisten serta cepat. Oleh karena itu, guru sebelum memberikan tes kepada siswa, sebaiknya terlebih dahulu menguji validitas tes yang telah dibuat menggunakan Piranti Lunak Artificial Intelligence (AI) Test-Analysis Software

\section{METODE PENELITIAN}

\section{A. Jenis Penelitian}

Jenis penelitian yang digunakan adalah kualitatif yang bersifat deskriptif. Penelitian ini sebelumnya dilakukan terlebih perancangan dan pembuatan produk perangkat lunak berbasis Artificial Intelligence (AI) pada uji validitas, tetapi hal itu hanya bersifat nilai tambah saja. Penelitian ini tetap menitikberatkan seberapa terukurnya (valid) tes buatan guru di Sekolah dengan menggunakan perangkat lunak berbasis Artificial Intelligence (AI).

Pengukuran validitas dilakukan dengan menguji tes-tes yang telah diberikan siswa SMP/MTs. Untuk mengetahui hasil uji tersebut, Piranti Lunak tersebut akan menampilkan yang data diharapkan dapat mengukur dan menguji tingkat butir tes yang telah dan akan diberikan.

\section{B. Data dan Sumber Data}

\section{Data}

Data penelitian untuk Artificial Intelligence $(A I)$ adalah tes-tes buatan guru bahasa bahasa Bugis SMPN 1 Labakkang Kabupaten Pangkep yang telah diberikan kepada siswa.

\section{Sumber Data}

Sumber data dalam penelitian ini adalah sumber-sumber tertulis atau dokumen dalam bentuk berupa silabus, kisi-kisi, soal (tes) yang telah dibuat guru bahasa Bugis SMPN 1 Labakkang Kabupaten Pangkep.

\section{Lokasi Penelitian}

Lokasi penelitian pada penelitian ini adalah SMPN 1 Labakkang Kabupaten Pangkep Provinsi Sulawesi Selatan. Jarak dari pusat kota Pangkep ke SMPN 1 Labakkang sekitar 8 km dan jarak ke ibukota Provinsi Sulawesi Selatan sekitar $50 \mathrm{~km}$. Pemilihan lokasi ini tidak terlalu jauh dan tidak terlalu dekat. Tempat penelitian ini dipilih karena merupakan salah satu sekolah unggulan di Kabupaten Pangkep dan masih mengajarkan bahasa bugis. 


\section{Journal Of Computer and Information System (J-CIS)}

ISSN 2622-0881 (online)

\section{Definisi Istilah}

Variabel pada penelitian ini perlu didefinisikan secara operasional agar tidak menimbulkan penafsiran ganda atau ambiguitas. Adapun definisi operasional yang perlu dijelaskan berkenaan dengan judul penelitian ini "Analisis Uji Validitas Tes Buatan Guru Bahasa Bugis dengan Menggunakan Artificial Intelligence (AI) Kelas IX 1 SMPN 1 Labakkang Kabupaten Pangkep" adalah sebagai berikut:

1. Analisis uji validitas adalah kesahihan suatu instrumen untuk mengukur sejauh mana suatu instrumen tersebut dalam menjalankan fungsinya. Instrumen dikatakan valid jika instrumen tersebut dapat digunakan untuk mengukur apa yang hendak diukur.

2. Tes buatan guru adalah segala sesuatu yang disiapkan guru berupa soal-soal uraian maupun pilihan ganda (multiple choice) yang disusun berdasarkan perangkat pembelajaran.

\section{E. Teknik Pengumpulan Data}

Teknik pengumpulan data yang akan digunakan dalam penelitian ini, sebagai berikut:

1. Observasi

Teknik ini dilakukan dengan cara mengadakan pengamatan di lapangan terhadap kegiatan pembelajaran di sekolah khususnya mata pelajaran bahasa Bugis. Dalam melakukan pengamatan, peneliti berperan sebagai pengamat partisipatif, yaitu terlibat dalam kegiatan sehari-hari orang yang sedang diamati atau yang digunakan sebagai sumber data penelitian (Sugiyono, 2009:145)

1. Wawancara

Teknik wawancara yang digunakan dalam penelitian ini adalah wawancara terbuka. Peneliti bertanya langsung kepada informan yang dipilih, yaitu pihak-pihak yang berkompeten yang dianggap mampu memberikan gambaran dan informasi yang digunakan untuk menjawab permasalahan yang ada dalam penelitian ini (Sugiyono, 2009:140). Dalam hal ini peneliti mewawancarai guru yang mengajar bahasa Bugis di SMPN 1 Labakkang tentang sejauh mana tes-tes yang diberikan guru ke siswa divalidasi atau tidak.

2. Dokumen

Metode dokumen adalah pengumpulan data melalui sumber-sumber tertulis atau dokumen yang ada pada informan dalam bentuk berupa silabus, RPP, kisi-kisi, soal (tes), dan hasil tes yang telah dilakukan guru serta penskoran masing-masing soal dan lembar jawaban siswa, baik yang berupa pilihan ganda maupun uraian.

\section{F. Teknik Analisis Data}

Teknik analisis data yang digunakan pada penelitian ini adalah tenik analisis deskriptif kualitatif. Teknik analisis data ini dilakukan dengan memberikan ulasan atau interpretasi terhadap data yang diperoleh sehingga menjadi lebih jelas dan bermakna dibandingkan dengan sekedar angka-angka. Langkahlangkahnya adalah reduksi data, penyajian data dengan bagan dan teks, kemudian penarikan kesimpulan.

Setelah data terkumpul, maka peneliti mengolah dan menganalisis secara deskriptif kualitatif. Piranti Lunak Artificial Intelligence (AI) (Test-Analysis Software) yang telah dibuat kemudian dimasukkan datadatanya berupa silabus, RPP, dan tes-tes yang diberikan pendidik serta hasil ujian tes peserta didik. Data tersebut dianalisis menggunakan rumus untuk menentukan validitas butir soal.

$$
r_{x y}=\frac{n \sum x y-\sum x \sum y}{\sqrt{\left(n \sum x^{2}-\left(\sum x\right)^{2}\right)\left(n \sum y^{2}-\left(\sum y\right)^{2}\right)}}
$$

Rumus tersebut merupakan acuan dasar dari hasil analisis dan beberapa langkah sederhana yang diaplikasikan pada Piranti Lunak Artificial Intelligence (AI) Test-Analysis Software. Kemudian hasil analisis tersebut berupa angka-angka, selanjutnya dideskripsikan kemudian dilakukan penarikan kesimpulan mengenai tes-tes buatan guru tersebut 


\section{HASIL PENELITIAN}

Setelah melakukan penelitian mengenai analisis uji validitas tes buatan guru bahasa Bugis di SMP Negeri 1 Labakkang selama kurang lebih 2 (dua) minggu, mulai tanggal 20 Januari - 20 Februari 2016 dengan jumlah peserta didik yang dianalisis, yaitu sebanyak 33 orang. Penggunaan Artificial Intelligence (AI) (TestAnalysis Software) untuk memudahkan pendidik menganalisis validitas tes buatan guru berupa tes uraian.

Berikut ini dipaparkan hasil penelitian dan pembahasan penelitian dari siswa SMPN Negeri 1 Labakkang Kelas IX. 1 adalah sebagai berikut:

\section{A. Hasil Penelitian}

1. Langkah Pengujian Validitas

a. Pengujian Indikator Penilaian RPP

b. Pengamatan Uji Validitas Tes Buatan Guru

c. Aktivitas Belajar Siswa

d. Respon Siswa

e. Pengujian Validitas pada Butir Soal

1) Menjalankan Artificial Intelligence (AI) (Test-Analysis Software)

2) Distribusi data Tes Buatan Guru pada Artificial Intelligence (AI) (Test-Analysis Software), hasilnya adalah sebagai berikut:

1) Melakukan aktivasi untuk mengisi data awal mengenai identitas sekolah, guru, mata pelajaran, KKM

2) Penginputan Data Peserta Didik, Indikator Penilaian, dan Jawaban Uraian

3) Menampilkan Output Uji Validitas Tes Buatan Guru Bahasa Bugis menggunakan Artificial Intelligence (AI) (Test-Analysis Software), hasilnya adalah sebagai berikut:

2. Hasil Analisis Uji Validitas Tes Buatan Guru SMPN 1 Labakkang

Uji validitas yang digunakan dengan menguji instrumen dengan menghitung nilai validitas dari setiap butir soal yang ada dalam instrument penelitian. Dalam hal ini di mana instrument diberikan kepada peserta didik sebanyak 33 responden. Kemudian skor-skor yang diperoleh dari instrument tersebut dihitung menggunakan rumus koefisien korelasi product moment dari rank spearman dengan bantuan program Artificial Intelligence (AI) dan SPSS.

Perhitungan uji validitas instrumen dilakukan dengan menggunakan rumus korelasi product moment. Data yang dianalisis diperoleh dari hasil uji instrumen validitas tes buatan guru belajar yang terdiri dari 7 butir soal uraian. Setelah data didapat maka dilakukan pengujian validitas yang dihitung dengan menggunakan microsoft excel dan SPSS. Kevalidan instrumen diukur berdasarkan kriteria validitas menurut Arikunto (2006: 72) yang menyatakan jika rhitung $\geq$ rtabel maka instrumen dinyatakan valid, tetapi jika rhitung < rtabel maka instrumen dinyatakan tidak valid. Diketahui bahwa rtabel menggunakan taraf signifikan $\alpha=0,05$ dengan $n=33$, maka diperoleh nilai rtabel sebesar 0,344 .

Instrumen uji validitas jumlah 7 soal yang telah diberikan, kemudian dihitung dengan menggunakan microsoft excel dan SPSS. Sebelum melakukan uji validitas terhadap 7 soal, terlebih dahulu dilakukan pengujian terhadap instrumen indikator penilaian RPP, pengamatan uji validitas, aktivitas peserta didik (siswa), respon peserta didik terhadap tes buatan guru bahasa Bugis, dan daya beda kesukaran. 
Tabel 4.2 Indikator Penilaian RPP

\begin{tabular}{|c|c|c|c|}
\hline \multirow{2}{*}{ No } & \multirow{2}{*}{ Komponen Rencana Pelaksanaan Pembelajaran } & \multicolumn{2}{|c|}{ Skor } \\
\hline & & Pengamat I & Pengamat II \\
\hline I & Perumusan Masalah & & \\
\hline 1 & Kejelasan masalah & 3 & 3 \\
\hline 2 & Sifat masalah & 3 & 3 \\
\hline 3 & Pemecahan melalui perbaikan pembelajaran & 2 & 3 \\
\hline II & Rumusan Kompetensi dan indikatornya & & \\
\hline 1 & Kejelasan rumusan & 4 & 4 \\
\hline 2 & Kelengkapan cakupan rumusan & 4 & 4 \\
\hline 3 & Kesesuaian indikator dengan kompetensi dasar & 4 & 4 \\
\hline III & Pemilihan dan pengorganisasian materi ajar & & \\
\hline 1 & Kesesuaian materi dengan kompetensi & 4 & 4 \\
\hline 2 & Kesesuaiannya dengan karakter peserta didik & 3 & 3 \\
\hline 3 & Keruntutan dan sistematika/organisasi materi & 3 & 4 \\
\hline 4 & Kesesuaian materi dengan alokasi waktu & 3 & 3 \\
\hline IV & Pemilihan sumber belajar/media pembelajaran & & \\
\hline 1 & $\begin{array}{l}\text { Kesesuaian sumber belajar/media pembelajaran dengan } \\
\text { kompetensi }\end{array}$ & 3 & 3 \\
\hline 2 & $\begin{array}{l}\text { Kesesuaian sumber belajar/media pembelajaran dengan materi } \\
\text { pembelajaran }\end{array}$ & 3 & 3 \\
\hline 3 & $\begin{array}{l}\text { Kesesuaian sumber belajar/media pembelajaran dengan } \\
\text { karakter peserta didik }\end{array}$ & 3 & 3 \\
\hline $\mathbf{V}$ & Strategi pembelajaran & & \\
\hline 1 & $\begin{array}{l}\text { Kesesuaian strategi dan metode pembelajaran dengan } \\
\text { kompetensi }\end{array}$ & 2 & 3 \\
\hline 2 & $\begin{array}{l}\text { Kesesuaian strategi dan metode pembelajaran } \\
\text { denganmateri pembelajaran }\end{array}$ & 2 & 2 \\
\hline 3 & $\begin{array}{l}\text { Kesesuaian strategi dan metode pembelajaran dengan } \\
\text { karakter peserta didik }\end{array}$ & 2 & 2 \\
\hline 4 & $\begin{array}{l}\text { Kesesuaian penerapan strategi pembelajaran dengan alokasi } \\
\text { waktu }\end{array}$ & 3 & 3 \\
\hline VI & Penilaian hasil belajar & & \\
\hline 1 & Kesesuaian teknik penilaian dengan kompetensi & 3 & 3 \\
\hline 2 & Kesesuaian item soal dengan indikator & 3 & 3 \\
\hline 3 & Kejelasan prosedur penilaian & 3 & 4 \\
\hline & TOTAL & 60 & 64 \\
\hline & NILAI & & \\
\hline
\end{tabular}

Keterangan

80-100 = Very Good (Sangat Baik)

40-59 = Good Enough (Cukup Baik)

$60-79=$ Good (Baik)

0-39 = Not Good (Kurang Baik)

Tabel 4.2 tentang indikator penilaian RPP yang diamati oleh dua (2) pengamat menunjukkan nilai sebesar 77.5 sehingga RPP ini termasuk dalam kategori baik atau good. Hal ini berarti bahwa Rencana Pelaksanaan Pembelajaran (RPP) yang digunakan memenuhi kriteria dan memang layak untuk digunakan di SMPN 1 Labakkang Kabupaten Pangkep. 
Tabel 4.3 Pengamatan Uji Validitas Tes Buatan Guru

\begin{tabular}{|c|c|c|c|c|}
\hline \multirow{2}{*}{ No } & \multirow{2}{*}{ ASPEK PENGAMATAN } & \multicolumn{2}{|c|}{ Terlaksana } & \multirow[t]{2}{*}{ Penilaian } \\
\hline & & Tdk & Ya & \\
\hline 1 & $\begin{array}{l}\text { Baca madecengi a'bacangnge ria se nainappa mubali pakkutanae ri } \\
\text { awa? } \\
\text { a. Aga kajajiang si pungeng de'nana wijanna Sawerigading ri tana Bone? } \\
\text { b. Aga akkatana pa'banuae lao si ita to mapakeang putewero? } \\
\text { c. Iga aseng pattelarenna tau manurungnge nennia aseng bandera naebbue? }\end{array}$ & & $\sqrt{ }$ & 4 \\
\hline 2 & $\begin{array}{l}\text { Lengkapi kalimat di bawah ini dengan awalan rangkap yang tepat! } \\
\text { a. De'na kuisseng rupai bolana amurekku sipongeng purana ........ loppo } \\
\text { b. Rilapangangnge maega tau ..... tanre pasajang. }\end{array}$ & & $\sqrt{ }$ & 4 \\
\hline 3 & Tuliskan 3 arti awalan rangkap! Berikan masing-masing 1 contoh! & & $\sqrt{ }$ & 3 \\
\hline 4 & $\begin{array}{l}\text { lya teppaja kusappa } \\
\text { Pagiling to maboko } \\
\text { Parewe to lao } \\
\text { Betuanna } . . . . . .\end{array}$ & & $\sqrt{ }$ & 4 \\
\hline 5 & $\begin{array}{l}\text { Rituppu bulu matanre } \\
\text { Inappa rololongeng } \\
\text { Betuanna ...... }\end{array}$ & & $\sqrt{ }$ & 4 \\
\hline 6 & Uki'i seddi elong minasa nainappa mu'uki toi betuanna! & & $\sqrt{ }$ & 4 \\
\hline 7 & Tuliskan ciri-ciri puisi klasik Bugis & & $\sqrt{ }$ & 3 \\
\hline & TOTAL & & & 26 \\
\hline & SKOR NILAI & & & 3.71 \\
\hline & PENILAIAN & & & $\begin{array}{c}\text { Sangat } \\
\text { Baik }\end{array}$ \\
\hline
\end{tabular}

Keterangan

$$
\begin{array}{ll}
3.1-4.0 & =\text { Very Good (Sangat Baik) } \\
2.1-3.0 & =\text { Good (Baik) } \\
1.1-2.0 & =\text { Good Enough (Cukup Baik) } \\
0.0-1.0 & =\text { Not Good (Kurang Baik) }
\end{array}
$$

Tabel 4.3 tentang Pengamatan Uji Validitas Tes Buatan Guru menunjukkan skor nilai 3.71 yang termasuk dalam kategori sangat baik atau very good. Tes menunjukkan kategori yang tinggi karena pada tabel 4.2 tentang indikator penilaian RPP menunjukkan angka yang baik. Tentu hasil yang diharapkan melalui uji validitas tes buatan guru akan merepresentasikan RPP yang telah disusun. 


\section{c. Aktivitas Belajar Siswa}

\section{Tabel 4.4 Aktivitas Belajar Siswa}

\begin{tabular}{|c|c|c|c|c|c|c|c|c|c|c|c|}
\hline \multirow{2}{*}{ No } & \multirow{2}{*}{ Nama Siswa } & \multicolumn{10}{|c|}{ Frekuensi berdasarkan Kategori Aktivitas Belajar Siswa } \\
\hline & & 1 & 2 & 3 & 4 & 5 & 6 & 7 & 8 & 9 & 10 \\
\hline 2 & A.Muarija Mutmainna AM & 1 & 3 & 1 & 1 & 0 & 4 & 2 & 2 & 2 & 0 \\
\hline 3 & A. Nurul Khalifatul Annisa & 1 & 3 & 1 & 0 & 1 & 4 & 2 & 2 & 2 & 0 \\
\hline 4 & Asmaul Husna & 1 & 3 & 1 & 1 & 0 & 4 & 2 & 2 & 2 & 0 \\
\hline 5 & Az Zahrah & 1 & 3 & 1 & 1 & 0 & 4 & 2 & 1 & 1 & 2 \\
\hline 6 & Darwis & 1 & 3 & 1 & 0 & 1 & 4 & 2 & 2 & 1 & 1 \\
\hline 7 & Hamsina & 1 & 4 & 1 & 0 & 0 & 4 & 2 & 2 & 2 & 0 \\
\hline 8 & Herianti & 1 & 4 & 1 & 0 & 0 & 4 & 2 & 2 & 2 & 0 \\
\hline 9 & Muh. Rauf & 1 & 3 & 1 & 0 & 0 & 4 & 2 & 2 & 1 & 2 \\
\hline 10 & Muh. Rifqi Pratama lqbal & 1 & 4 & 1 & 0 & 0 & 4 & 2 & 2 & 2 & 0 \\
\hline 11 & Muhammad Akbar Azis & 1 & 3 & 1 & 0 & 0 & 4 & 2 & 2 & 1 & 2 \\
\hline 12 & Munawarah & 1 & 4 & 1 & 0 & 0 & 4 & 2 & 2 & 2 & 0 \\
\hline 13 & Musdalifa & 1 & 4 & 1 & 0 & 0 & 4 & 2 & 2 & 2 & 0 \\
\hline 14 & Musdalifa Munir & 1 & 2 & 1 & 0 & 0 & 4 & 2 & 1 & 1 & 4 \\
\hline 15 & Naelani & 1 & 2 & 1 & 0 & 0 & 3 & 2 & 2 & 1 & 4 \\
\hline 16 & Nur Afni Syafitri & 1 & 3 & 1 & 0 & 2 & 4 & 1 & 2 & 2 & 0 \\
\hline 17 & Nur Alisa Puspita Sari & 1 & 3 & 1 & 0 & 1 & 4 & 2 & 2 & 2 & 0 \\
\hline 18 & Nur Islamiah & 1 & 3 & 1 & 0 & 0 & 3 & 2 & 1 & 1 & 4 \\
\hline 19 & Nur Maulindah Umar & 1 & 3 & 1 & 1 & 0 & 3 & 2 & 2 & 2 & 1 \\
\hline 20 & Nur Fajrimani & 1 & 4 & 1 & 0 & 0 & 4 & 2 & 1 & 1 & 2 \\
\hline 21 & Nurul Fitri & 1 & 4 & 1 & 0 & 0 & 4 & 2 & 2 & 2 & 0 \\
\hline 22 & Pira Yunita & 1 & 3 & 1 & 0 & 0 & 4 & 2 & 2 & 1 & 2 \\
\hline 23 & Rahmat & 1 & 4 & 1 & 0 & 0 & 4 & 2 & 1 & 1 & 2 \\
\hline 24 & Rinawati & 1 & 4 & 1 & 0 & 0 & 4 & 2 & 2 & 2 & 0 \\
\hline 25 & Sabaruddin M. Nur & 1 & 3 & 1 & 0 & 0 & 4 & 2 & 1 & 1 & 3 \\
\hline 26 & Sapriadi Rasyid & 1 & 3 & 1 & 0 & 0 & 4 & 2 & 1 & 1 & 3 \\
\hline 27 & Siti Aulia Pratiwi & 1 & 4 & 1 & 0 & 0 & 4 & 2 & 2 & 2 & 0 \\
\hline 28 & Sitti Hardianti Rukmana & 1 & 2 & 1 & 0 & 0 & 4 & 2 & 1 & 1 & 4 \\
\hline 29 & Tamsil Pratama & 1 & 2 & 1 & 0 & 0 & 4 & 2 & 2 & 1 & 3 \\
\hline 30 & Tenriani Andi Baso & 1 & 4 & 1 & 0 & 0 & 4 & 2 & 1 & 1 & 2 \\
\hline 31 & Vira Yuniar & 1 & 3 & 1 & 0 & 0 & 4 & 2 & 2 & 1 & 2 \\
\hline 32 & Wildasari & 1 & 2 & 1 & 0 & 0 & 4 & 2 & 1 & 1 & 4 \\
\hline 33 & Yudhistira & 1 & 3 & 1 & 0 & 0 & 4 & 2 & 2 & 1 & 2 \\
\hline & JUMLAH & 33 & 105 & 33 & 5 & 5 & 129 & 65 & 56 & 46 & 49 \\
\hline
\end{tabular}


Berdasarkan tabel 4.4 aktivitas belajar siswa berdasarkan kategori aktivitas belajar siswa, maka frekuensi tertinggi yaitu siswa berdiskusi yaitu 129. Untuk kategori mengajukan pertanyaan dan menjawab pertanyaan hanya memiliki frekuensi sebesar masing-masing 5 . Hal ini menunjukkan bahwa siswa lebih senang berdiskusi, tetapi masih pasif terhadap mengajukan pertanyaan dan mengajukan jawaban baik kepada guru maupun sesama siswa.

\section{d. Respon Siswa terhadap Tes Buatan Guru Bahasa Bugis Tabel 4.5 Respon Peserta Didik terhadap Tes Buatan Guru Bahasa Bugis}

\begin{tabular}{|c|c|c|c|c|c|c|}
\hline & $\begin{array}{l}\text { Scale } \\
\text { Mean if } \\
\text { Item } \\
\text { Deleted }\end{array}$ & $\begin{array}{c}\text { Scale } \\
\text { Variance if } \\
\text { Item } \\
\text { Deleted }\end{array}$ & $\begin{array}{l}\text { Corrected } \\
\text { Item-Total } \\
\text { Correlation }\end{array}$ & $\begin{array}{l}\text { Cronbach's } \\
\text { Alpha if } \\
\text { Item } \\
\text { Deleted }\end{array}$ & $\begin{array}{c}\text { Tabel } \\
r\end{array}$ & $\begin{array}{l}\text { Tingkat } \\
\text { Validitas }\end{array}$ \\
\hline Amanda Sukira Nurdin & 75.43 & 200.418 & .535 & .934 & 0.344 & Valid \\
\hline $\begin{array}{l}\text { A. Muarija Mutmainna } \\
\text { AM }\end{array}$ & 76.07 & 194.995 & .740 & .931 & 0.344 & Valid \\
\hline $\begin{array}{l}\text { A. Nurul Khalifatul } \\
\text { Annisa }\end{array}$ & 75.86 & 202.901 & .324 & .936 & 0.344 & Tidak Valid \\
\hline Asmaul Husna & 74.93 & 200.379 & .565 & .933 & 0.344 & Valid \\
\hline Az Zahrah & 76.07 & 196.533 & .662 & .932 & 0.344 & Valid \\
\hline Darwis & 74.79 & 196.027 & .720 & .932 & 0.344 & Valid \\
\hline Hamsina & 75.93 & 194.995 & .740 & .931 & 0.344 & Valid \\
\hline Herianti & 75.79 & 201.874 & .355 & .935 & 0.344 & Valid \\
\hline Muh. Rauf & 74.93 & 203.764 & .303 & .936 & 0.344 & Tidak Valid \\
\hline $\begin{array}{l}\text { Muh. Rifqi Pratama } \\
\text { lqbal }\end{array}$ & 75.07 & 191.918 & .784 & 931 & 0.344 & Valid \\
\hline Muhammad Akbar Azis & 75.36 & 204.709 & .251 & .936 & 0.344 & Tidak Valid \\
\hline Munawarah & 75.14 & 194.901 & .825 & .931 & 0.344 & Valid \\
\hline Musdalifa & 75.50 & 200.885 & .371 & .935 & 0.344 & Valid \\
\hline Musdalifa Munir & 76.07 & 204.379 & .273 & .936 & 0.344 & Tidak Valid \\
\hline Naelani & 75.79 & 191.874 & .815 & .930 & 0.344 & Valid \\
\hline Nur Afni Syafitri & 75.29 & 204.374 & .275 & .936 & 0.344 & Tidak Valid \\
\hline Nur Alisa Puspita Sari & 75.64 & 204.709 & .304 & .936 & 0.344 & Tidak Valid \\
\hline Nur Islamiah & 75.93 & 193.148 & .728 & .931 & 0.344 & Valid \\
\hline Nur Maulindah Umar & 74.86 & 198.440 & .469 & .934 & 0.344 & Valid \\
\hline Nur Fajrimani & 76.00 & 189.846 & .828 & .930 & 0.344 & Valid \\
\hline Nurul Fitri & 75.36 & 199.016 & .458 & .934 & 0.344 & Valid \\
\hline Pira Yunita & 76.14 & 194.132 & .740 & .931 & 0.344 & Valid \\
\hline Rahmat & 76.14 & 190.440 & .736 & .931 & 0.344 & Valid \\
\hline Rinawati & 75.57 & 204.264 & .268 & .936 & 0.344 & Tidak Valid \\
\hline Sabaruddin M. Nur & 76.00 & 203.538 & .289 & .936 & 0.344 & Tidak Valid \\
\hline Sapriadi Rasyid & 76.07 & 196.995 & .639 & .932 & 0.344 & Valid \\
\hline Siti Aulia Pratiwi & 75.79 & 204.489 & .282 & .936 & 0.344 & Tidak Valid \\
\hline Sitti Hardianti Rukmana & 76.07 & 192.687 & .749 & .931 & 0.344 & Valid \\
\hline Tamsil Pratama & 75.93 & 198.533 & .435 & .935 & 0.344 & Valid \\
\hline Tenriani Andi Baso & 75.93 & 199.302 & .454 & .934 & 0.344 & Valid \\
\hline Vira Yuniar & 76.07 & 198.071 & .585 & .933 & 0.344 & Valid \\
\hline Wildasari & 75.00 & 201.231 & .463 & .934 & 0.344 & Valid \\
\hline Yudhistira & 75.50 & 194.885 & .715 & .932 & 0.344 & Valid \\
\hline
\end{tabular}


Berdasarkan tabel 4.5 respon peserta didik terhadap tes buatan guru bahasa Bugis menunjukkan ada 9 siswa (27\%) yang tidak valid atau respon yang kurang baik. Sedangkan, respon peserta didik terhadap tes buatan guru bahasa Bugis menunjukkan valid atau respon yang baik berjumlah 24 siswa $(73 \%)$.

\section{e. Koherensi Kompetensi Dasar dan Jumlah Soal}

Tabel 4.6 Koherensi Kompetensi Dasar dan Jumlah Soal

\begin{tabular}{cclc}
\hline No. & $\begin{array}{c}\text { Nomor } \\
\text { KD }\end{array}$ & \multicolumn{1}{c}{ Rumusan Kompetensi Dasar (KD) } & Jumlah Soal \\
\hline 1 & KD 3.3.1 & $\begin{array}{l}\text { Memahami fungsi sosial struktur Teks dan unsur kebahasaan dalam cerita } \\
\text { Pau-paunna Pamulanna Tana Bone }\end{array}$ & 1 soal uraian \\
\hline 2 & KD 3.3.2 & Mehamahami teks kebahasaan awalan rangkap melalui lisan maupun tulisan & 1 soal uraian \\
\hline 3 & KD 4.4.2 & Melengkapi kalimat dengan menggunakan awalan rangkap & 1 soal uraian \\
\hline 4 & KD 3.3.3 & $\begin{array}{l}\text { Memahami bait atau larik-larik sastra / puisi Bugis baik melalui lisan } \\
\text { maupun tulisan }\end{array}$ & 2 soal uraian \\
\hline 5 & KD 4.4.3 & Menangkap makna puisi Bugis Elong Minasa & 2 soal uraian \\
\hline
\end{tabular}

Tabel 4.6 memperlihatkan terdapat lima (5) Kompetensi Dasar yang digunakan guru-guru dalam membuat soal. Terdapat 3 Kompetensi Dasar yang dibuat hanya masing-masing soal dan terdapat 2 Kompetensi Dasar yang masing-masing terdapat 2 soal. Kompetensi Dasar 3.3.1 tentang Memahami fungsi sosial struktur Teks dan unsur kebahasaan dalam cerita Pau-paunna Pamulanna Tana Bone memiliki jumlah butir soal sebanyak 1 soal.

Kompetensi Dasar 3.3.2 tentang Mehamahami teks kebahasaan awalan rangkap melalui lisan maupun tulisan memiliki jumlah butir soal sebanyak 1 soal. Kompetensi Dasar 4.4.2 tentang Melengkapi kalimat dengan menggunakan awalan rangkap memiliki jumlah butir soal sebanyak 1 soal. Kompetensi Dasar 3.3.3 tentang Memahami bait atau larik-larik sastra / puisi Bugis baik melalui lisan maupun tulisan memiliki jumlah butir soal sebanyak 2 soal. Kompetensi Dasar 4.4.3 tentang Menangkap makna puisi Bugis Elong Minasa memiliki jumlah butir soal sebanyak 2 soal.

\section{f. Daya Pembeda dan Tingkat Kesukaran}

Tabel 4.9 Daya Pembeda dan Tingkat Kesukaran

\begin{tabular}{|c|c|c|c|c|c|c|c|}
\hline \multirow{2}{*}{$\begin{array}{c}\text { Nomor } \\
\text { Butir } \\
\text { Soal }\end{array}$} & \multirow[b]{2}{*}{$\begin{array}{l}\text { Rata- } \\
\text { rata }\end{array}$} & \multirow{2}{*}{$\begin{array}{c}\text { Skor } \\
\text { Tertinggi }\end{array}$} & \multicolumn{2}{|c|}{ Skor Rata-rata } & \multirow{2}{*}{$\begin{array}{c}\text { Tingkat } \\
\text { Kesukaran }\end{array}$} & \multirow[b]{2}{*}{$\begin{array}{c}\text { Daya } \\
\text { Pembeda }\end{array}$} & \multirow{2}{*}{$\begin{array}{c}\text { Kualitas } \\
\text { Soal }\end{array}$} \\
\hline & & & $\begin{array}{l}\text { Kelompok } \\
\text { Atas }\end{array}$ & $\begin{array}{l}\text { Kelompok } \\
\text { Bawah }\end{array}$ & & & \\
\hline 1 & 6.7 & 9 & 7.19 & 6.19 & $\begin{array}{c}0.74 \\
\text { Mudah } \\
\end{array}$ & 0.11 & $\begin{array}{c}\text { Jelek } \\
\text { (soal ditolak) } \\
\end{array}$ \\
\hline 2 & 2.76 & 4 & 3.06 & 2.5 & 0.69 & 0.14 & Jelek \\
\hline & & & & & Sedang & & (soal ditolak) \\
\hline 3 & 4.82 & 6 & 5.5 & 4.31 & $\begin{array}{c}0.8 \\
\text { Mudah }\end{array}$ & 0.2 & $\begin{array}{c}\text { Jelek } \\
\text { (soal ditolak) }\end{array}$ \\
\hline 4 & 4.45 & 5 & 4.88 & 4 & $\begin{array}{c}0.89 \\
\text { Mudah }\end{array}$ & 0.18 & $\begin{array}{c}\text { Jelek } \\
\text { (soal ditolak) }\end{array}$ \\
\hline 5 & 4.15 & 5 & 4.81 & 3.44 & $\begin{array}{c}0.83 \\
\text { Mudah } \\
\end{array}$ & 0.27 & $\begin{array}{c}\text { Jelek } \\
\text { (soal ditolak) } \\
\end{array}$ \\
\hline 6 & 7.03 & 10 & 9.13 & 4.75 & $\begin{array}{c}0.7 \\
\text { Sedang } \\
\end{array}$ & 0.44 & $\begin{array}{c}\text { Sangat Baik } \\
\text { (soal diterima) }\end{array}$ \\
\hline 7 & 4.42 & 5 & 4.94 & 3.88 & $\begin{array}{c}0.88 \\
\text { Mudah }\end{array}$ & 0.21 & $\begin{array}{c}\text { Jelek } \\
\text { (soal ditolak) }\end{array}$ \\
\hline
\end{tabular}


Berdasarkan tabel 4.9 daya pembeda dan tingkat kesukaran dari ketujuh butir soal diperoleh kategori tingkat kesukaran dan kategori daya pembeda serta kualitas soal. Kategori pertama, yaitu tingkat kesukaran soal terdiri dari mudah dan sedang. Yang mencakup tingkat kesukaran kategori mudah itu pada butir soal nomor 1,3, 4, 5, dan 7. Kategori ini menjadi mudah dikarenakan rata-rata dibagi skor tertinggi itu lebih besar dari 7 atau $\mathrm{p}>7$. Kategori kedua pada tingkat kesukaran soal, yaitu kategori mudah mencakup pada butir soal nomor 2 dan 6. Kategori ini termasuk sedang dikarenakan rata-rata dibagi skor tertinggi itu antara 0.50 sampai dengan 0.70 atau $0.50 \leq \mathrm{p} \leq 0.70$.

Selanjutnya, untuk menentukan kualitas soal, maka daya pembeda dan tingkat kesukaran perlu adanya perpaduan dimaksudkan untuk membedakan antara siswa yang telah menguasai materi dengan siswa yang tidak/belum/kurang menguasai materi. Berdasarkan tabel 4.6 daya pembeda dan tingkat kesukaran dari ketujuh butir soal diperoleh kategori serta kualitas soal. Kategori pertama, yaitu kuliatas soal jelek yang mencakup daya pembeda dan tingkat kesukaran dikombinasikan yaitu kualitas soal jelek itu pada butir soal nomor 1, 2, 3, 4, 5, dan 7. Kualitas soal jelek dikarenakan tingkat perpaduan tingkat kesukaran dan daya pembeda tidak memenuhi target. Kemudian kualitas soal sangat baik, yaitu kategori tingkat kesukaran dikombinasikan dengan daya pembeda menghasilkan rumusan kualitas soal yang sangat baik.

\section{g. Analisis Validitas Butir Soal}

Tabel 4.11 Analisis Validitas Butir Soal

\begin{tabular}{|c|c|c|c|c|c|}
\hline $\begin{array}{l}\text { Butir } \\
\text { Soal }\end{array}$ & Koefisien Korelasi & Kategori Validitas & $\mathrm{r}_{\text {tabel }}$ & Komentar & Ket \\
\hline 1 & 0.83 & Sangat Tinggi & 0.344 & Valid & \\
\hline 2 & 0.44 & Sedang & 0.344 & Valid & \\
\hline 3 & 0.56 & Sedang & 0.344 & Valid & \\
\hline 4 & 0.82 & Sangat Tinggi & 0.344 & Valid & \\
\hline 5 & 0.76 & Tinggi & 0.344 & Valid & \\
\hline 6 & 0.76 & Tinggi & 0.344 & Valid & \\
\hline 7 & 0.69 & Tinggi & 0.344 & Valid & \\
\hline
\end{tabular}

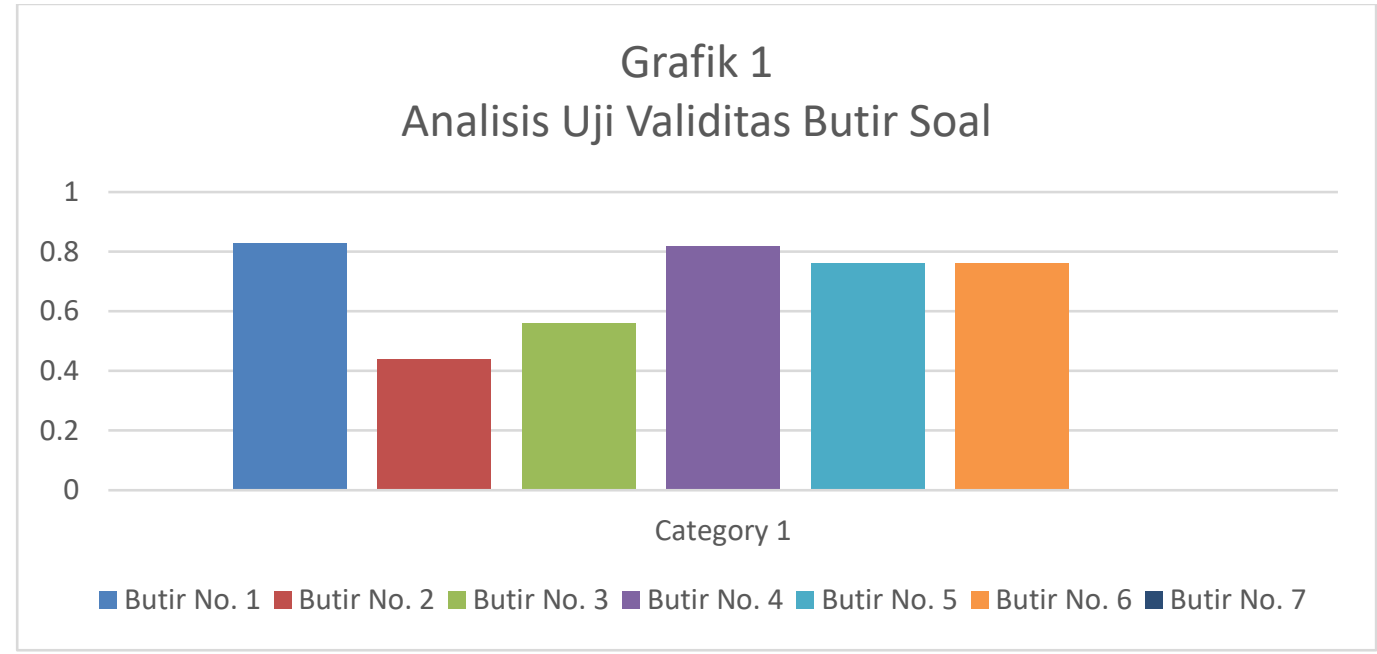

Validitas empiris sama dengan validitas kriteria yang berarti bahwa validitas ditentukan berdasarkan kriteria. Validitas empiris diperoleh melalui hasil uji coba tes kepada responden yang setara dengan responden yang akan dievaluasi atau diteliti. Validitas butir yang diukur dengan besaran yang 


\section{Journal Of Computer and Information System (J-CIS)}

ISSN 2622-0881 (online)

menggunakan tes sebagai suatu kesatuan (keseluruhan butir) sebagai kriteria untuk menentukan validitas butir dari tes itu. Penentuan validitas empiris berdasarkan tabel 4.11 pada SMPN 1 Labbakang Kabupaten Pangkep menunjukkan pengujian validitas tes-tes yang diberikan pendidik ke peserta didik menggunakan Piranti Lunak Artificial Intelligence (AI) (Test-Analysis Software), maka diperoleh analisis tiga kategori validitas soal, kategori sangat tinggi terdapat dua butir soal, yaitu butir soal ke-1 dan ke-4 (28.6\%). Kategori selanjutnya itu kategori tinggi, yaitu tiga butir soal berkategori tinggi, yaitu butir soal nomor ke-5, ke-6, dan ke-7 (42.8\%). Untuk kategori terakhir, yaitu kategori sedang, terdapat dua butir soal berkategori sedang, yaitu butir soal nomor 2 dan 3 (28.6).

Koefisien korelasi masing-masing butir soal berbeda bahkan diantara kesamaan kategori sangat tinggi, tinggi, dan sedang memiliki perbedaan koefisien korelasi. Butir soal kategori sangat tinggi, yaitu butir soal poin satu (0.83) dan butir soal poin empat (0.82). Selanjutnya kategori tinggi, koefisien korelasinya itu terdiri butir soal poin lima dan enam itu memiliki kesamaan (0.76) dan koefisien korelasi terbawah dari kategori tinggi pada butir soal poin tujuh (0.69). Untuk kategori sedang berdasarkan koefisien korelasinya itu terdiri dari butir soal poin tiga, yaitu 0.56 dan butir soal poin dua, yaitu 0.44 .

\section{PEMBAHASAN}

Berdasarkan hasil penelitian dan pengumpulan data di SMPN 1 Labakkang Kabupaten Pangkep, pengujian dimulai dengan menguji validitas isi dan konstruk pada konten dan butir soal, kemudian memasukan hasil penskoran soal-soal tes buatan guru bahasa Bugis SMPN 1 Labakkang Kabupaten Pangkep, lalu pengujian dilakukan beberapa kali untuk uji validitas secara manual maupun menggunakan SPSS 22 sekaligus sebagai perbandingan dari pengujian menggunakan Piranti Lunak Artificial Intelligence (AI) (Test-Analysis Software).

1. Validatas Isi dan Konstruk

Validitas isi dan konstruk suatu pada uji validitas tes dapat dilihat dari segi isi dan mengukur aspek berpikir pada tes buatan guru bahasa Bugis Kelas IX.1 SMPN 1 Labakkang Kabupaten Pangkep. Tes hasil belajar sesuai materi tes tersebut benar-benar representatif terhadap pelajaran yang diberikan dan mengukur tujuan khusus tertentu yang sejajar dengan materi atau isi pelajaran yang diberikan. Materi yang diajarkan harus betul-betul tertera dalam kurikulum dan diusahakan tercapainya sejak saat penyusunan dengan cara memerinci materi kurikulum atau materi buku pelajaran. Selanjutnya, validitas konstruksi pada tes buatan guru bahasa Bugis Kelas IX.1 SMPN 1 Labakkang Kabupaten Pangkep sesuai indikator penilaian RPP dalam kategori baik. Selanjutnya pengamatan uji validitas tes buatan guru berdasarkan butir-butir soal yang membangun tes tersebut mengukur setiap aspek berpikir seperti yang disebutkan dalam tujuan pembelajaran khusus menunjukkan tingkat yang sangat baik. Untuk respon peserta didik terhadap tes buatan guru bahasa Bugis menunjukkan dua pertiga kevaliditasannya yang diinginkan.

Validitas isi pada tes buatan guru bahasa Bugis SMPN 1 Labakkang dapat dilihat berdasarkan butir-butir tes (soal) yang tercermin pada keseluruhan konten atau materi (RPP dan Kompetensi Dasar) yang diujikan atau yang seharusnya dikuasai secara proporsional. Penelaahan kisi-kisi tes dari RPP memastikan telah mewakili atau mencerminkan keseluruhan konten atau materi yang dikuasai secara proporsional.

Selanjutnya validitas konstruk ini bukanlah merupakan konstruksi seperti bangunan atau susunan, tetapi berupa rekaan psikologis yang berkaitan dengan aspek-aspek ingatan, pemahaman, aplikasi, analisis, sintesis, dan evaluasi. Validitas isi dan konstruk yang terdapat dalam suatu tes buatan guru bahasa Daerah menggunakan Artificial Intelligence (AI) (Test-Analysis Software) kelas IX. 1 SMPN 1 Labakkang sesuatu dengan tes atau instrumen terdeskripsikan dalam RPP, Pengamatan Uji Validitas, dan Respon Peserta Didik terhadap Tes Buatan Guru Bahasa Daerah. 


\section{Validitas Empiris/Kriteria}

Validitas empiris/kriteria pada tes buatan guru bahasa Bugis SMPN 1 Labakkang adalah membuat tes yang memiliki kriteria yang sama dengan tes sejenis yang telah ada (standar tes). Melalui uji coba akan dianalisis tingkat kesukaran dan kualitas soal di samping diuji validitas. Berdasarkan uji coba tersebut, soal-soal akan diperbaiki dan disempurnakan sehingga menghasilkan tes yang mendekati standarnya.

Berdasarkan tingkat validitas isi, konstruk, dan empiris/kriteria tes buatan guru Bahasa Daerah Bugis menggunakan Piranti Lunak Artificial Intelligence (AI) (Test-Analysis Software) kelas IX 1 di SMPN 1 Labakkang Kabuapten Pangkep dari serangkaian pengujian dinyatakan valid. Oleh karena itu, tes buatan guru ini layak digunakan dan telah memenuhi kriteria kevadilitasan. Kemudian pengukuran validitasnya dinilai dari tiga aspek validitas yaitu validitas isi, konstruk, dan kriteria. Ketiga aspek validitas ini dinyatakan valid. Meskipun telah valid, tetapi pada tingkat kesukaran tes (soal) yang dibuat guru bahasa Bugis tidak memenuhi kriteria. Terlihat hanya satu tes (soal) yang kualitasnya bagus dan tes (soal) yang lain itu kualitasnya jelek. Perlu adanya upaya untuk memperbaiki tes yang diberikan guru bahasa Bugis terutama pada tingkat kesukaran soal.

\section{KESIMPULAN DAN SARAN}

\section{A. Kesimpulan}

Berdasarkan uraian dan analisis dapat ditarik kesimpulan mengenai analisis uji validitas tes buatan guru bahasa Bugis menggunakan Piranti Lunak Artificial Intelligence (AI) (Test-Analysis Software) sebagai berikut adalah Artificial Intelligence (AI) (Test-Analysis Software) ini sudah memenuhi persyaratan tentang keefektifan dan keefisienan dibandingkan dengan melakukan secara manual kemudian dilakukan implementasi di SMPN 1 Labakkang pada Mata Pelajaran Bahasa Daerah (Bahasa Bugis) di Kelas IX. 1, maka terdapat empat instrumen dalam menguji validitas, yaitu 1) penilaian RPP yang berada pada tataran kategori baik atau valid. 2) pengamatan uji validitas yang berada pada kategori sangat baik atau sangat valid. 3) respon siswa yang terdiri tiga kategori validitas soal (27\%) yang tidak valid atau respon yang kurang baik dan respon peserta didik terhadap tes buatan guru bahasa Bugis menunjukkan valid atau respon yang baik berjumlah 24 siswa (73\%). 4) analisis butir soal yang terdiri dari kategori sangat tinggi terdapat dua butir soal, yaitu butir soal ke-1 dan ke-4 (28.6\%), kategori tinggi, yaitu tiga butir soal berkategori tinggi, yaitu butir soal nomor ke-5, ke-6, dan ke-7 (42.8\%), dan kategori sedang, terdapat dua butir soal berkategori sedang, yaitu butir soal nomor 2 dan 3 (28.6\%). Pengujian validitas tes buatan guru ini menyatakan bahwa tes buatan guru ini berdasarkan pengkategorian validitas isi, konstruk, dan kriteria/empiris adalah valid.

\section{B. Saran}

Adapun saran yang dapat kami sebagai penulis adalah sebagai berikut:

1. Perancangan dan pembuatan Piranti Lunak Artificial Intelligence (AI) (Test-Analysis Software) ini akan terasa sempurna jika ada teman-teman dari Fakultas Bahasa dan Sastra, Prodi Bahasa Daerah yang mau dan bisa meneruskan dan menambahkan Piranti Lunak lainnya yang berhubungan dengan Bahasa Daerah (Bahasa Bugis).

2. Dapat pula dilengkapi dengan pengujian reliabilitas demi kesempurnaan analisis tes buatan guru nanti kedepannya 


\section{Journal Of Computer and Information System (J-CIS) ISSN 2622-0881 (online)}

\section{DAFTAR PUSTAKA}

Arikunto, Suharsimi. 1991. Manajemen Penelitian. Jakarta: Rineka Cipta Azwar, Saifuddin. 1988. Sikap Manusia Teori dan Pengukurannya. Yogyakarta: Liberty . 2003. Sikap Manusia, Teori dan Pengukurannya. Yogyakarta: Pustaka Pelajar

Borg, W.R. \& Gall, M.D. Gall. 1989. Educational Research: An Introduction, Fifth Edition. New York: Longman.

Djaali, dkk. 2000. Pengukuran dalam Pendidikan. Jakarta: Program Pascasarjana UI.

Harjanto. 2000. Perencanaan Pengajaran. Jakarta: Rineka Cipta.

Kusumadewi, Sri. 2003. Artificial Intelligence (Teknik dan Aplikasinya). Graha. Ilmu. Yogyakarta

Matondang, Zulkifli. Validitas dan Reliabilitas Suatu Instrumen Penelitian. Jurnal Tabularasa PPs UNIMED Vol.6 No.1, Juni 2009.

Nurgiyantoro, Burhan. 2012. Penilaian Pembelajaran Bahasa. Yogyakarta: BPFE.

Nurkancana, Wayan. 1992. Evaluasi Hasil Belajar, Surabaya: Usaha Nasional

Nur, Mohamad. 1987. Teori Tes. Surabaya: IKIP Surabaya

Plomp, T. 1999. Principles and Method of Development Research. London. DIm. van den Akker, J., Branch, R.M., Gustafson, K., Nieveen, N., \&. Design Approaches and Tools in Educational and Training. Dordrecht: Kluwer Academic Publisher.

Rich, Elaine dan Knight, Kevin. (1991). Artificial Intelligence. McGraw-Hill Inc,. New York

Seels, Barbara B. \& Rita C. Richey. 1994. Teknologi Pembelajaran. Seri Pustaka Teknologi Pendidikan No.12

Silverius, Suke. 1991. Evaluasi Hasil Belajar dan Umpan Balik. Jakarta: PT Gramedia Widiasarana Indonesia

Sudjana, Nana. 2004. Penilaian Hasil Proses Belajar Mengajar. Bandung: Remaja Rosdakarya

Sugiyono. 2008. Metode Penelitian Kuantitatif Kualitatif dan R\&D. Bandung: Alfabeta.

Suharsimi Arikunto. 2012. Dasar-Dasar Evaluasi Pendidikan. Jakarta : PT Bumi Aksara.

Sujadi. 2003. Metodologi Penelitian Pendidikan. Jakarta: Rineka cipta

Sukaca, Agus. 2013. Statistik Deskriptif: Penyajian Data, Ukuran Pemusatan Data, dan Ukuran Penyebaran Data.

Sutojo. 2010. Artificial Intelligence (AI). Semarang. Yogyakarta: Andi Yogyakarta.

Suryabrata, Sumadi. 2000. Pengembangan Alat Ukur Psikologis. Yogyakarta: Andi Yogyakarta

Suyanto. 2007. Artificial Intelligence: Searching, Reasoning, Planning, and Learning. Bandung: Informatika

Thoha, M. Chabib. 1994. Teknik Evaluasi Pendidikan. Jakarta: PT Raja Grafindo Persada 